\title{
A STUDY ON AGRICULTURE FINANCE: NEW PARADIGM FOR GUJARAT AGRICULTURE SECTOR
}

KEY WORDS: Agriculture sector, Agriculture Finance, Agriculture in Gujarat, Crop yield

\section{Dr. Ronak A. Mehta}

Assistant Professor, Shri Manilal Kadakia College of Management, Computer Studies, Commerce and Science - Ankleshwar.

India as developing country is hugely depending upon agriculture due to labour intensive technique adopted in agriculture sector. Gujarat is greater contributor because of its demographical advantage and crop pattern. Despite of industrial growth in Gujarat state, it can be said that Gujarat still did not lost its potential and growth in playing its part in agricultural development. Agriculture finance on other side has its crucial role to play in growth of agriculture Finance. The present paper indicates the potential and performance of agriculture in Gujarat state and also attempt has been made to address agriculture finance performance in Gujarat. Gujarat has not preserved and developed its natural resources when it comes to farming. Farmers also suffer due to lack of irrigation facilities. The methods of cultivation in most areas of India are still ancient. Farmers are not able to adopt modernization due to lack of fund and exposure towards it. It is the government which concentrate more on agriculture finance by providing micro credit, crop loan and crop insurance, which aim to uplift stand of living of the farmers.

\section{INTRODUCTION}

Gujarat is the one of the fastest growing states of India. The state has adopted a novel pattern of progress with the strategic development of the key sectors like energy, industry and agriculture for which it has achieved ambitious double digit growth rate since 10th Five Year Plan period. The state constitutes about 6.2 per cent of total geographical area and 4.99 per cent of total population of India. As per Census 2011, about 3.47 crores people of the state live in rural areas forming about 57.4 per cent of its total population (GoI, 2011). About 70.5 per cent of total workers in the state are rural based.Agriculture continues to be the primary occupation for the majority of rural people in the state. About 51.8 per cent of total workers are cultivators and agricultural labourers.

Thus, the agriculture in the state has been a major source of labour absorption. Moreover, agriculture provides indirect employment to large portion of population in agro-based occupations. Thus, prosperity and well being of people in Gujarat is closely linked with agriculture and allied activities. The State is divided into 7 sub agro-climatic zones based on the characteristics of their agriculture and climate. The State is endowed with abundant natural resources in terms of varied soil, climatic conditions and diversified cropping pattern suitable for agricultural activities.

\section{Nature \& Scope:}

It can be done at both micro level \& macro level. Micro finance deals with different sources or areas from where the funds are available for agriculture in the economy. It includes activities like, lending procedure, rules, regulations, monitoring \& controlling of different agricultural credit institutions. Hence micro finance is related to financing of agriculture. It is including the future use of funds. Therefore, micro finance deals with the tasks relating to total needs of the credit to agricultural sector the terms \& conditions under which the credit is available or borrow \& the method of use of total credit for the development of agriculture sector, while micro finance refers to the financial management of individual farm business.

\section{Literature Review}

Sudha Narayanan (2015) in her research paper titled "The Productivity of Agricultural Credit in India" examined the association between the agricultural credit and agricultural GDP (Gross Domestic Production) in India. The state-level penal data from the year 1995 to 2012 has been used collectively to measure the relationship. The outcome showed that agriculture credit has played a significant role to respond against the background constraints of the agriculture sector. However, it had also been observed that agricultural credit had not transformed fully into agricultural GDP growth.
Dr.Shobha Chaudhari and Reetu (2015) suggested in the paper titled "Role of Institutional Credit to Agriculture sector" that there should be coordination between the different agencies which providing loans and MSP (Minimum Support Price) should be higher than the cost of production. Good quality warehouses should be opened and the skill of farming should be provided to the peasants Kempe Gowda. P (2014) found that a cultivator is in almost perpetual need of credit both for production and consumption. Traditionally his needs were met by the landlord-trader moneylender complex involving usurious interest rates and other exploitative practices. The high-cost of deposit, the low interest rate on advances, very low deposit mobilisation in the rural branches has been come out as a major reason behind the low profitability of the commercial bank.

Dr.Siddaraju (2013) in his research paper titled "Growth of Agriculture Sector in India - A Time for New Thinking" found that Improvement in water management and irrigation system is required. Diversification of crops also helps to generate high agriculture revenue. It was also suggested to improve and extend agro- processing at the farm, traditional small industry, and modern Industry levels.

Kapil Dave (2013) in his article titled "Agriculture growth of Gujarat" revealed that the growth rate of Gujarat (2007-2012) was very less and it's below Madhya Pradesh, Chhattisgarh, Rajasthan, Jharkhand, Andhra Pradesh and Assam. It has been observed by the CAG (Computer and Auditor General of India) that the Krishi Mahotsav, launched by Gujarat government has not achieved complete victory. It has been also observed that the management of soil health card was also incompetent.

\section{Research Methodology}

The study has been conducted with objective to understand and state the position of agriculture in Gujarat, in light of provided agriculture finance by private and public sector including government. For the above said objective researcher has collected secondary data from various source like websites and journals with non probability convenient sampling methods. Data has been processed with excel and brought out conclusion in form of tables and charts.

The compound annual growth rate of gross cropped area, total agricultural production and yield has exhibited wide fluctuations during annual plan 1990-91 to 11 th Five Year Plan. The crop area, yield and production have decelerated drastically during the annual plan period (1990-91), as well as during the 9th plan period. However, during 10th Five Year Plan period, there has been a significant growth in area, yield and production, which has increased significantly at the rate 
of 5.27 per cent, 20.54 per cent and 14.50 per cent, respectively. Despite of efforts being taken by the government to achieve 4 percent rate of growth during XI FYP, the rate of growth in crop productivity was negative. The crop yield has decelerated at the rate of 1.23 percent per annum, whereas area has increased at the rate of 2.24 percent per annum. It may worth to note here that the gross cropped area has increased by almost 18.2 percent in four years period, i.e. increased from 121.1 lakh hectares in 2007-08 to 143.2 lakh hectares in 2010-11. The extent of fluctuation in agricultural production is also quite evident from Figure.

Table : 1 . Crops Pattern Area wise (Gujarat State)

\begin{tabular}{|l|l|l|l|l|}
\hline year & $\begin{array}{l}\text { Gross } \\
\text { cropped area }\end{array}$ & \multicolumn{3}{l}{ all major crops } \\
\hline & (000 ha) & Area & production & yields \\
\hline & & $(000$ ha $)$ & $(000 \mathrm{MT})$ & $(\mathrm{Kg} / \mathrm{ha})$ \\
\hline $1990-91$ & 10635 & 8956 & 10456 & 1167 \\
\hline $1995-96$ & 10996 & 9376 & 12223 & 1304 \\
\hline $2000-01$ & 10497 & 7745 & 7500 & 968 \\
\hline $2005-06$ & 11495 & 9148 & 20999 & 2296 \\
\hline $2006-07$ & 11807 & 9748 & 19617 & 2012 \\
\hline $2007-08$ & 12110 & 10092 & 24582 & 2436 \\
\hline $2008-09$ & 11571 & 9544 & 19710 & 2065 \\
\hline $2009-2010$ & 11138 & 9057 & 18447 & 2037 \\
\hline $2010-11$ & 14316 & 10786 & 25319 & 2348 \\
\hline
\end{tabular}

(Source: data.gov.in.)

Among these programmes, the Rashtirya Krishi Vikas Yojana (RKVY), Kisan Credit Card Scheme (KCC) and Agricultural Technology Management (ATMA) programme are the major ones. It is evident from Table 19 that about Rs 60257 lakh has been spent under RKVY during last five years, out of which Rs 33100 has been spent during the year 2010-11.

Table 2: Credit Disbursed under Rashtirya Krishi Vikas Yojana (RIVY) (Rs. In lakhs)

\begin{tabular}{|c|c|c|c|c|}
\hline Year & $\begin{array}{c}\text { Earn } \\
\text { grant }\end{array}$ & $\begin{array}{c}\text { Grant } \\
\text { recieved by } \\
\text { GOI }\end{array}$ & Expenditure & $\begin{array}{c}\text { Expenditure } \\
\text { as \% of grant }\end{array}$ \\
\hline $2007-08$ & 5151 & 4761 & 4761 & 100 \\
\hline $2008-09$ & 24339 & 24339 & 22654.3 & 91.1 \\
\hline $2009-10$ & 38619 & 38619 & 27652.3 & 71.6 \\
\hline $2010-11$ & 38863 & 38863 & 37142.8 & 95.6 \\
\hline $2011-12$ & 50090 & 25000 & 33100 & 132.4 \\
\hline Total & 157062 & 131582 & 125310.4 & 95.2 \\
\hline
\end{tabular}

(Source:data.gov.in.)

\section{Significance Of Agricultural Finance:}

- It affects to Agro, Socio, and Economic development of the country.

- It plays crucial role in strengthening the farm business \& impact of productivity of scares resources.

- They helped to use new technological inputs for farming \& increasing the agricultural productivity of farmer.

- It reduces regional economic imbalances between rural \& urban area.

- It is needed to create the supporting infrastructure for adoption of new technology.

\section{Advantages Of Ān Agricultural Finance:}

- To fulfil their basic needs.

- Different loans are available for different purposes.

- Agricultural loans are generally low-cost loans.

- Providing funding for rebuilding \& renovation.
- Lack of diversification.

- Lengthy process.

- Lower level of education.

- Lack of awareness towards it.

- High interest rate.

- No security on mortgage asset.

\section{CONCLUSION}

In conclusion it can be said that over a period of years it is observed that since 1991 to 2011 the crop production has been increased with quite a growth rate in 2010 and 2011 yeild has been increased drastically, which happens might be or not agriculture finance grant received and other sources of agriculture finance from private and public sectors. Various form agriculture finance like crop loan, crop insurance, kishan credit card are promoted by the medium of kishan mela at various places in districts of Gujarat state. Gujarat state has been benefitted in various way by getting grants from the government but data also suggested it has been impacted well and production and yield both has been increased. It is also found there has been -0.2945 correlation coefficient between grant received, which indicates grant received is negatively impacting crop production in Gujarat state, but if we look at real picture like expenses Gujarat government spending has 0.3517 correlation with the crop yield that shows spending has contributed in developing productivity. Hence it can conclude agriculture finance has impact in creating better living for farmers residing in Gujarat state.

\section{REFERENCES:}

1. open govt.data platform. (2013, may 13). Retrieved January 15, 2015, from data govt web site:http://data.gov.in/catalog/gdp-india-and-major-sectorseconomy-share-each-sector-gdp-and-growth-rate-gdp-and-other\# web catalog tabs block_1

2. Planning commission. (2013,April 1). Retrieved January 15,2015, from Govt of india website: http://planningcommission. gov.in/hackathon/ index.php? sector=Agriculture and_Rural_Development

3. Indian economy snapshot. (2018, April). Retrieved may 15, 2018, from Indian brand equity Foundation: https://www.ibef.org/industry/agricultureindia.aspx 11

4. Naiyer Azam, D. M. (2015). Agriculture Play Crucial Role in the Life of Indian Economy. International Journal of scientific research and management, 22391144.

5. Kapil Dave. (2013, may 14). times of India. Retrieved February 4, 2015, from India times: https://timesofindia.indiatimes.com/city/ahmedabad/Gujaratranked-8th-in-agricultural-growth-Centre/articleshow/20040305.cms

6. Mihir Shah, Rangu Rao, P.S. Vijay Shankar. (April 2007). Rural credit in India. Economic and political weekly.

7. Sudha Narayanan. (2015). The Productivity of Agricultural Credit in India. Indira Gandhi Institute of Development Research.

8. Dr.Shobha Chaudhari, Reetu. (2015). Role of Institutional Credit To Agriculture Sector. Indian Journal of Applied Research, 137-138.

9. Kempe Gowda. P. (October 2014). Rural Finance: Analysis of Growth of Organised Agriculture Credit. International Multidiciplinary Research Journal Research Direction, 1-7.

\section{Disadvantages Of An Agricultural Finance:}

- Seasonality of agricultural business.

- Natural calamities.

- Production risk

|www.worldwidejournals.com $\mid$ 